\title{
FAKTOR-FAKTOR YANG BERHUBUNGAN DENGAN PARTISIPASI KONTAKTANI DALAM PERENCANAAN PROGRAM PENYULUHAN PERTANIAN (Kasus WKUPP Nyalindung, Kabupaten Sukabumi)
}

\section{FACTORS RELATED TO CONTACT FARMER PARTICIPATION IN AGRICULTURAL EXTENSION PROGRAM PLANNING (Case of Rural Extension Center at Nyalindung, Sukabumi)}

\author{
Herawati dan Ismail Pulungan
}

\begin{abstract}
The main objective of this research was to determine the extent of contact-farmer participation in agricultural extension program planning i.e., in collecting data, in compiling the data collected, in attending meeting, in discussing and in giving suggestions, and in authenticating the program and activities that followed. To meet this objective, 30 contactfarmers registered in the Contact-Farmer Association (Gapoktan) in Rural Extension Unit at Nyalindung Subdistrict, District of Sukabumi were interviewed. The research results showed that both the contact-farmers' internal and external factors were highly correlated with their participation in planning Agricultural Extension program and activities.
\end{abstract}

Key words: Participation, Contact-farmer, Extension Program

\section{Pendahuluan}

Partisipasi erat hubungannya dengan kegiatan pembangunan, sehingga usaha menumbuhkan dan mengembangkan partisipasi masyarakat menempati posisi yang sangat penting dalam seluruh proses pembangunan dalam arti luas. Penyuluh pertanian diarahkan untuk mengubah persepsi dan perilaku petani. Petani diarahkan untuk mencapai hasil seperti peningkatan pengetahuan dan keterampilan, efisiensi manajemen usahatani dan mekanisme kerja yang mendorong partisipasi aktif petani (Asean Productivity Organization, 1994).

Salah satu strategi penyuluhan pertanian dalam membangun kemandirian prakarsa, tanggung jawab serta partisipasi masyarakat tani dalam pembangunan pertanian yang berencana dan terukur adalah dengan terwujudnya Programa Penyuluhan Pertanian di setiap tingkatan wilayah. Bentuk partisipasi kontaktani dalam perencanaan programa penyuluhan adalah hadir dan mengajukan saran dalam rapat programa, dan diterimanya saran/usul kontaktani. Saran yang diterima berarti telah memberikan sumbangan yang lebih besar di dalam programa penyuluhan.

Pembuatan programa bersama masyarakat menyiratkan suatu pandangan luas tentang partisipasi masyarakat. Partisipasi merupakan keterlibatan masyarakat dalam tindakan dan refleksi, atau suatu proses pemberdayaan dan keterlibatan aktif dalam pengambilan keputusan pada seluruh kegiatan pembuatan programa, dalam mengakses dan mengendalikan sumber daya dan institusi (Cristovao, Timothy, and Portela, 1994). 
Kontaktani dibutuhkan keterlibatannya dalam penyusunan programa penyuluhan, sehingga penyuluh tidak hanya melakukan sesuatu untuk petani, tetapi melakukan sesuatu bersama petani. Petani ikut serta memberikan masukan dalam penyusunan programa penyuluhan, terutama mengenai kebutuhan, keinginan dan masalah-masalah yang dihadapinya dalam mengelola usahatani. Berpartisipasinya kontaktani dalam programa penyuluhan pertanian akan menyebabkan petani merasa memiliki program tersebut; dengan demikian program yang direncanakan diharapkan dapat direalisasikan secara efektif.

Sejalan dengan uraian di atas, secara spesifik penelitian ini bertujuan untuk menentukan: (1) keragaman faktor internal dan eksternal kontaktani di WKUPP Nyalindung. (2) tingkat partisipasi kontaktani dalam perencanaan programa. (3) hubungan antara faktor internal dan eksternal dengan tingkat partisipasi kontaktani dalam perencanaan programa penyuluhan pertanian.

\section{Metode Penelitian}

Penelitian ini menggunakan rancangan penelitian survei yang bersifat deskriptif korelasional. Penelitian ini dilaksanakan di Kecamatan Nyalindung Kabupaten Sukabumi Provinsi Jawa Barat, pada bulan Maret sampai dengan April 2005. Pemilihan lokasi penelitian diambil dengan kriteria : (1) kriteria berbagai usaha pertanian di Nyalindung bisa mewakili lokasi Sukabumi, (2) Kantor Penyuluhan Pertanian (KPP) dan kontaktani aktif, (3) petani mampu mendirikan tempat musyawarah secara swadaya dan (4) sarana transportasi dan komunikasi.

Populasi penelitian adalah semua kontaktani di Wilayah Kerja Unit Penyuluhan Pertanian (WKUPP) Nyalindung sebanyak 64 kontaktani dan sampel penelitian diambil secara purposive sebanyak 30 orang, merupakan kontaktani gabungan kelompok tani (Gapoktan). Analisis data digunakan dalam menjawab masalah dan menguji hipotesis yang telah dirumuskan dengan menggunakan uji korelasi rank Spearman (Siegel, 1994).

\section{Hasil dan Pembahasan}

\section{$\underline{\text { Faktor Internal Kontaktani }}$}

Pendidikan formal responden dalam penelitian ini cukup bervariasi mulai dari yang mengikuti Sekolah dasar sampai yang mengikuti pendidikan di Perguruan Tinggi. Hasil wawancara dengan kontaktani menggambarkan bahwa tingkat pendidikan formal sebagian besar kontaktani sampai dengan Sekolah Dasar termasuk dalam kategori rendah. Rendahnya tingkat pendidikan formal karena pada masa itu lembaga pendidikan formal yang lebih tinggi, seperti SLTP dan SLTA tempatnya jauh dan sulit dijangkau, sebab sarana angkutan dan jalan belum ada seperti sekarang ini.

Pengalaman yang dimiliki responden sebagai kontaktani terbesar pada tingkat kategori sedang yaitu antara 7,4 - 22,1 tahun sebesar 50\%. Hal ini terjadi karena tidak adanya penggantian ketua dalam kelompok. Pekerjaan kontak tani yang tergolong dalam kategori sedang sebanyak 40\%, artinya kontaktani selain bertani juga memiliki pekerjaan lain sebagai tambahan pendapatan keluarga.

Tingkat pendapatan sebagian besar kontak tani $(70,3 \%)$ termasuk dalam kategori sedang sampai tinggi (Tabel 1). Dilihat dari tingkat pendapatan sudah memenuhi persyaratan sebagai kontaktani. Salah satu persyaratan menjadi kontaktani adalah mempunyai status sosial ekonomi yang tinggi dan membaik, sehingga dengan tingkat sosial yang demikian diharapkan mereka akan bekerja lebih baik. 
Tabel 1. Faktor Internal Kontak Tani

\begin{tabular}{|c|c|c|c|c|}
\hline \multirow[t]{2}{*}{ No } & \multirow{2}{*}{$\begin{array}{c}\text { Faktor internal } \\
\text { Kontaktani }\end{array}$} & \multirow[t]{2}{*}{ Kategori } & \multicolumn{2}{|c|}{ Jumlah } \\
\hline & & & Jiwa & $(\%)$ \\
\hline \multirow[t]{3}{*}{1.} & \multirow[t]{3}{*}{ Pendidikan } & Tinggi (Perguruan Tinggi) & 1 & 3 \\
\hline & & Sedang (SLTP - SLTA) & 12 & 40 \\
\hline & & Rendah (s.d SD) & 17 & 57 \\
\hline \multirow[t]{3}{*}{2.} & \multirow[t]{3}{*}{ Pengalaman } & Tinggi (Skor $>22.2$ tahun) & 12 & 40 \\
\hline & & Sedang (Skor 7.4-22.1 thn) & 15 & 50 \\
\hline & & Rendah (Skor $<7.4$ tahun) & 3 & 10 \\
\hline \multirow[t]{3}{*}{3.} & \multirow[t]{3}{*}{ Pekerjaan } & Tinggi (Memiliki > 2 jenis ) & 11 & 37 \\
\hline & & Sedang (Memiliki 2 jenis) & 12 & 40 \\
\hline & & Rendah (Memiliki 1 jenis ) & 7 & 23.3 \\
\hline \multirow[t]{3}{*}{4.} & \multirow[t]{3}{*}{ Pendapatan } & Tinggi ( > Rp12 105 396) & 20 & 67 \\
\hline & & Sedang (Rp $4929738-R p)$ & 4 & 13.3 \\
\hline & & Rendah ( < Rp 4929738 ) & 6 & 20 \\
\hline
\end{tabular}

\section{$\underline{\text { Faktor Eksternal Kontaktani }}$}

Intensitas penyuluhan sebagian besar kontaktani termasuk dalam kategori sedang yaitu sebesar 63\% (Tabel 2). Hal ini berarti kontaktani cukup sering mengikuti kegiatan penyuluhan dan materi penyuluhan sesuai dengan kebutuhan petani. Penyuluh di UPP Nyalindung rata-rata memberikan penyuluhan di setiap kelompok tani 2 bulan sekali. Setelah ditelusuri lebih lanjut, ditemukan bahwa selain jadwal rutin penyuluh datang ke kelompok, kontaktani juga sering mengundang penyuluh untuk datang membahas masa- lah yang muncul di kelompok. Penyuluhan yang dilakukan dengan melihat kebutuhan nyata petani dan membantu petani dalam pemecahan masalah, memotivasi petani untuk mengikuti penyuluhan pertanian.

Tingkat kekosmopolitan kontaktani berada pada tingkat kategori sedang sebesar $47 \%$, artinya kontaktani menyatakan cukup sering mencari informasi tentang usahatani keluar dari sistem sosialnya (sifat kekosmopolitan). Hal ini menunjukkan bahwa kontaktani di Kecamatan Nyalindung cukup kosmopolit dan sifat ini dapat meningkatkan usahataninya.

Tabel 2 Faktor Eksternal Kontaktani

\begin{tabular}{|c|c|c|c|c|}
\hline \multirow[t]{2}{*}{ No } & \multirow[t]{2}{*}{ Faktor Eksternal Kontaktani } & \multirow[t]{2}{*}{ Kategori } & \multicolumn{2}{|c|}{ Jumlah } \\
\hline & & & Jiwa & $(\%)$ \\
\hline \multirow[t]{3}{*}{1.} & \multirow[t]{3}{*}{ Intensitas Penyuluhan } & Tinggi (Skor > 5.6) & 6 & 20 \\
\hline & & Sedang (Skor 3.46 - 5.6) & 19 & 63 \\
\hline & & Rendah (Skor < 3.46) & 5 & 17 \\
\hline \multirow[t]{3}{*}{2.} & \multirow[t]{3}{*}{ Kekosmopolitan } & Tinggi (Skor > 7.294) & 12 & 40 \\
\hline & & Sedang (Skor 4.246-7.29) & 14 & 47 \\
\hline & & Rendah (Skor < 2.426) & 4 & 13 \\
\hline \multirow[t]{3}{*}{3.} & \multirow[t]{3}{*}{ Frekuensi Komunikasi } & Tinggi (Skor > 11,778) & 16 & 53 \\
\hline & & Sedang (Skor $7.362-11.8$ ) & 6 & 20 \\
\hline & & Rendah (Skor < 7.362) & 8 & 27 \\
\hline \multirow[t]{3}{*}{4.} & \multirow[t]{3}{*}{ Keikutsertaan Organisasi } & Tinggi (sebagai pengurus) & 8 & 27 \\
\hline & & Sedang (Sebagai anggota) & 17 & 56 \\
\hline & & Rendah (Tidak ada) & 5 & 17 \\
\hline
\end{tabular}


Frekuensi komunikasi tergolong dalam kategori tinggi yaitu sebesar 53\%. Frekuensi komunikasi di sini adalah pertemuan kontaktani dengan anggota kelompok untuk memecahkan masalah yang dihadapi dalam kelompoknya. Ini berarti komunikasi yang sering terjadi antara sesama petani dapat menimbulkan rasa akrab dan kekeluargaan. Keikutsertaan kontaktani dalam organisasi di lingkungannya termasuk dalam kategori sedang sebesar $56 \%$, artinya kontaktani di lingkungannya juga menjadi pemimpin dan panutan masyarakat sekitarnya.

\section{Tingkat Partisipasi Kontaktani dalam Penyusunan Programa \\ $\underline{\text { Penyuluhan Pertanian }}$}

Pengukuran partisipasi kontaktani
melalui kehadiran dalam pertemuan-
pertemuan pembuatan programa, mengajukan
saran/usul dalam pertemuan tersebut dan
diterima atau tidaknya saran yang diberikan
kontaktani dalam rapat.

Tabel 3 Partisipasi Kontaktani dalam Programa Penyuluhan Pertanian.

\begin{tabular}{|c|c|c|c|c|}
\hline \multirow[t]{2}{*}{ No } & \multirow[t]{2}{*}{ Partisipasi dalam } & \multirow[t]{2}{*}{ Kategori } & \multicolumn{2}{|c|}{ Jumlah } \\
\hline & & & Jiwa & $(\%)$ \\
\hline \multirow[t]{3}{*}{1.} & \multirow[t]{3}{*}{ Pengumpulan data } & Tinggi (Skor 3) & 9 & 30 \\
\hline & & Sedang (Skor 2) & 3 & 10 \\
\hline & & Rendah (Skor 1) & 18 & 60 \\
\hline \multirow[t]{3}{*}{2.} & \multirow{3}{*}{$\begin{array}{l}\text { Penyusunan Konsep } \\
\text { Programa }\end{array}$} & Tinggi (Skor > 5.8) & 16 & 54 \\
\hline & & Sedang (Skor 3.3-5.8) & 10 & 33 \\
\hline & & Rendah $($ Skor $<3.3)$ & 4 & 13 \\
\hline \multirow[t]{3}{*}{3.} & \multirow[t]{3}{*}{ Pengesahan Programa } & Tinggi (Skor > 2.04) & 7 & 23 \\
\hline & & Sedang (Skor $1.03-2.04$ ) & 14 & 47 \\
\hline & & Rendah $($ Skor $<1.03)$ & 9 & 30 \\
\hline
\end{tabular}

Tingkat partisipasi kontaktani dalam pengumpulan data tergolong dalam kategori rendah $(60 \%)$. Hal ini terjadi karena suatu tatacara pengikutsertaan orang-orang atau instansi dalam perencanaan programa. Di mana dalam kegiatan ini tidak semua kontaktani ikut melakukan kegiatan tertentu seperti mengumpulkan data, menyusun, merevisi, dan mengesahkan programa. Kontaktani yang terlibat pada pengumpulan data adalah kontaktani andalan WKUPP yang berasal dari kontaktani itu sendiri. Tetapi jika ada kontaktani yang ingin ikut dalam kegiatan itu, boleh saja dan tidak tertutup kemungkinannya bagi mereka. Penerapan tatacara pengumpulan data ditafsirkan oleh kontaktani secara kaku. Pengertian mereka diwakili oleh kontaktani andalan WKUPP pada kegiatan-kegiatan tertentu adalah bahwa mereka benar-benar diwakili tanpa perlu lagi berpartisipasi dalam kesempatan itu, walaupun peluang bagi mereka tetap masih terbuka. Keadaan ini menyebabkan saran/usul diperoleh hanya berasal dari kontaktani andalan.

Partisipasi dalam kegiatan penyusunan konsep programa penyuluhan pertanian di UPP Nyalindung termasuk dalam kategori tinggi sebanyak 54\%, artinya kontaktani sudah memiliki kesadaran untuk hadir dan memberikan saran dalam rapat sehingga diharapkan program tersebut dapat membantu petani dalam peningkatan kesejahteraan. Partisipasi dalam pengesahan programa berada pada kategori sedang sebesar $47 \%$. Hal ini terjadi karena sebagian kontak tani yang hadir pada pertemuan penyusunan tidak hadir dalam pengesahan. Pelaksanaan rapat pengesahan bertepatan dengan acara keluarga. 
Partisipasi masyarakat dalam tahapan perencanaan dan pengambilan keputusan dilakukan melalui pertemuan yang melibatkan masyarakat tani dalam hal ini kontaktani. Pada pelaksanaan terhadap peserta pertemuan yang cenderung pendiam, tidak ingin menginterupsi, kurang percaya diri dan tidak memiliki kemampuan verbal, selalu terabaikan sehingga suasana pertemuan dikuasai secara mutlak oleh orang-orang tertentu yang merasa melebihi peserta lain.

Pengalaman mereka menunjukkan beberapa program penyuluhan tanpa keikutsertaan mereka tidak sesuai dengan kebutuhan dan kondisi petani di lapangan.
Dilihat dari kegiatan perencanaan programa maka dapat dikatakan bahwa tingkat partisipasi kontaktani cukup baik walaupun belum seperti yang diharapkan sehingga masih perlu untuk terus ditingkatkan.

Hubungan Faktor Internal dengan Tingkat Partisipasi Kontaktani

Hasil uji korelasi rank spearman menunjukkan bahwa pendidikan, pengalaman sebagai kontaktani, pekerjaan dan pendapatan berhubungan dengan partisipasi dalam programa penyuluhan pertanian seperti terlihat pada Tabel 4.

Tabel 4. Hubungan antara Faktor internal Kontak Tani dan Partisipasi dalam Programa Penyuluhan Pertanian.

\begin{tabular}{|l|c|c|c|}
\hline \multirow{3}{*}{ Faktor Internal } & \multicolumn{3}{|c|}{ Tingkat Partisipasi } \\
\cline { 2 - 4 } & Tingkat Kehadiran & Mengajukan saran & Diterima saran \\
\cline { 2 - 4 } & \multirow{2}{*}{ Koefisien Korelasi } & Koefisien Korelasi & \multirow{2}{*}{ Koefisien Korelasi } \\
\hline Pendidikan & 0,141 & $0,381^{*}$ & 0,204 \\
\hline Pengalaman & $0,388^{*}$ & $0,530^{* *}$ & $0,393^{*}$ \\
\hline Pekerjaan & $0,461^{*}$ & $0,401^{*}$ & 0,264 \\
\hline Pendapatan & $0,382^{*}$ & 0,282 & 0,218 \\
\hline
\end{tabular}

\footnotetext{
Keterangan : * Berhubungan nyata pada $\alpha=0,05$

** Berhubungan sangat nyata pada $\alpha=0,01$
}

Hipotesis penelitian yang menyatakan bahwa faktor internal kontaktani berhubungan secara nyata dengan partisipasi kontaktani dalam penyusunan programa ditolak karena ada tiga faktor internal yang tidak berhubungan secara nyata.

Ada suatu kenyataan bahwa seseorang ditokohkan oleh masyarakat sering didasarkan atas berbagai faktor antara lain faktor kepandaian, pengalaman, kekayaan dan pendidikan. Biasanya faktor yang terakhir ini dianggap penting karena dengan melalui pendidikan yang diperoleh, seseorang mudah berkomunikasi dengan orang luar dan cepat tanggap terhadap inovasi.
Kontaktani rata-rata mengenyam pendidikan Sekolah Dasar sampai SLTP, beberapa SMA dan satu orang sarjana yang berarti kontaktani memiliki kemampuan membaca dan berbahasa Indonesia. Dengan demikian dapat dimaklumi bila ada hubungan secara nyata antara tingkat pendidikan dengan derajat aktifitas mengajukan saran dalam rapat programa. Hasil penelitian menunjukkan semakin tinggi tingkat pendidikan seseorang semakin tinggi pula partisipasinya dalam mengajukan saran.

Pengalaman berhubungan secara nyata dengan tingkat partisipasi dalam kehadiran dan diterimanya saran serta berhubungan sangat nyata dengan pengajuan saran. Hal ini 
menunjukkan semakin lama responden sebagai kontaktani, maka partisipasinya semakin tinggi. Pengalaman yang dimiliki sebagian besar kontaktani mendorong untuk aktif dalam pertemuan programa. Kontaktani mengatakan bahwa responden yang sudah lama menjadi kontaktani sudah terbiasa bekerja sosial untuk masyarakat tanpa diupah tapi mereka merasa senang, merasa dihargai dengan memberi saran sehingga selalu berpartisipasi aktif dalam kehadiran. Sebagai contoh bila ada pertemuan/rapat di UPP, dengan diberitahu melalui telepon atau pesan, tanpa undangan pun mereka bersedia hadir.

Gambaran jenis pekerjaan ini berhubungan secara nyata dengan tingkat partisipasi dalam kehadiran dan mengajukan saran. Jenis pekerjaan yang ada di lokasi penelitian selain pekerjaan pokok sebagai petani juga memiliki pekerjaan lain sebagai tambahan pendapatan keluarga. Ternyata banyaknya jenis pekerjaan bukan merupakan halangan untuk kehadiran dalam penyusunan programa.

Sejalan dengan penemuan hasil penelitian menunjukkan bahwa banyaknya jenis pekerjaan mempunyai tingkat partisipasi yang lebih tinggi untuk mengajukan saran. Hal ini disebabkan kontaktani merasa memiliki tanggung jawab moral sebagai ketua kelompok, keinginan memberi informasi dan ingin tahu pogram yang akan dilakukan selama setahun.

Pendapatan kontaktani berhubungan dengan tingkat kehadirannya dalam pembuatan programa. Pendapatan yang tinggi dari usahatani maupun luar usahatani menyebabkan kontaktani memiliki kemampuan finansial yang cukup untuk menghadiri rapat programa di UPP. Hasil penelitian ini sesuai teori Maslow yaitu apabila kebutuhan fisiologi sudah terpenuhi akan meningkat ke jenjang lebih tinggi dalam hal ini adalah kebutuhan sosialisasi, interaksi dengan orang lain. Wujud dari kebutuhan ini adalah ikut berpartisipasi dalam programa penyuluhan pertanian.

\section{Hubungan Faktor Eksternal dengan Tingkat Partisipasi}

Hasil uji korelasi rank Spearman menunjukkan bahwa intensitas penyuluhan, kekosmopolitan, frekuensi komunikasi dan keikutsertaan dalam organisasi mempunyai hubungan yang nyata dan sangat nyata dengan partisipasi dalam programa penyuluhan pertanian (Tabel 5).

Tabel 5. Hubungan antara Faktor Eksternal Kontak Tani dengan Partisipasi dalam Programa Penyuluhan Pertanian.

\begin{tabular}{|l|c|c|c|}
\hline \multirow{2}{*}{ Faktor Eksternal } & \multicolumn{3}{|c|}{ Tingkat Partisipasi } \\
\cline { 2 - 4 } & Tingkat Kehadiran & Mengajukan saran & Diterimanya saran \\
\cline { 2 - 4 } & Korelasi & Korelasi & Korelasi \\
\hline $\begin{array}{l}\text { Intensitas } \\
\text { Penyuluhan }\end{array}$ & $\mathbf{0 , 4 8 0 * *}$ & 0,070 & 0,313 \\
\hline Kekosmopolitan & $\mathbf{0 , 5 2 8 * *}$ & $\mathbf{0 , 3 7 7 *}$ & $\mathbf{0 , 4 0 6 *}$ \\
\hline $\begin{array}{l}\text { Frekuensi } \\
\text { Komunikasi }\end{array}$ & $\mathbf{0 , 4 2 4 *}$ & 0,235 & 0,244 \\
\hline Ikut Organisasi & $\mathbf{0 , 4 5 3 *}$ & $\mathbf{0 , 5 2 8 * *}$ & $\mathbf{0 , 4 2 9} *$ \\
\hline
\end{tabular}

Keterangan : * Berhubungan nyata pada $\alpha=0,05$

** Berhubungan sangat nyata pada $\alpha=0,01$ 
Hipotesis yang menyatakan bahwa faktor eksternal kontaktani berhubungan secara nyata dengan tingkat partisipasi kontaktani dalam perencanaan program ditolak karena ada dua faktor eksternal yang tidak berhubungan secara nyata.

Intensitas penyuluhan berhubungan secara nyata dengan tingkat kehadiran kontaktani. Hal ini berarti semakin tinggi intensitas penyuluhan maka kesadaran untuk mengetahui pentingnya programa sangat tinggi, tetapi tingginya kehadiran mereka tidak selaras dengan keaktifan dalam mengajukan saran.

Tingkat kekosmopolitan kontaktani di Sukabumi cukup tinggi. Pengalaman berkunjung ke daerah lain dan melihat kemajuan yang sudah dicapai oleh petani lain baik sebagai utusan dari UPP maupun dengan kunjungan yang bersifat pribadi dapat menambah perbendaharaan pengetahuan dan keterampilan tentang usahatani, merangsang diri dan kelompok agar lebih dinamis, dan menimbulkan semangat kerja untuk meningkatkan produktifitas. Hal ini membuat kontaktani lebih banyak mengajukan saran/usul dalam pembahasan programa. Kunjungan dan interaksi dapat mempengaruhi sikap dan mental kontaktani yang biasanya akan lebih cepat menyambut dan berpartisipasi pada setiap usaha yang bertujuan memperbaiki atau membangun usaha pertanian masyarakat.

Komunikasi efektif berarti sumber informasi dan penerima dapat saling merespon. Menurut Pareek (1984), jenis komunikasi berdasarkan arah komunikasi yaitu ke bawah, ke atas dan horisontal. Komunikasi kontaktani dengan pihak UPP Nyalindung cukup intensif artinya kontaktani merasa butuh dengan informasi yang berhubungan dengan usahataninya karena selama ini inovasi-inovasi yang diperoleh kebanyakan berasal dari UPP. Selain itu komunikasi antara sesama kontaktani terjadi dengan tukar menukar informasi teknologi dan pemasaran. Programa penyuluhan sebagai wadah dalam kegiatan pertanian sehingga mereka memiliki keinginan untuk hadir dalam pertemuan programa penyuluhan.

Ikut dalam organisasi memiliki hubungan yang nyata dengan partisipasi kontaktani dalam kehadiran, mengajukan saran dan diterimanya saran. Kebutuhan berorganisasi cukup tinggi sehingga wajar bila kontaktani berpartisipasi dalam penyusunan, pembahasan dan pengesahan. Keadaan tersebut diduga erat kaitannya dengan kontaktani yang mengurus suatu organisasi memiliki kemampuan untuk menyampaikan gagasan dalam suatu forum diskusi/musyawarah.

Kelembagaan lokal yang ada di desa, kelembagaan kelompok masyarakat memegang peranan penting dalam kegiatan penyuluhan. Hal ini berarti adanya komunikasi di antara anggota kelompoktani, sesama kontaktani dan dengan kelembagaan lainnya sangat penting dalam menentukan sukses tidaknya kegiatan penyuluhan sesuai programa yang telah disusun.

Kontaktani di samping sebagai ketua kelompok juga ikut berperan dalam lembaga desa baik sebagai anggota maupun pengurus. Jenis organisasi tersebut yaitu LKMD, Koperasi, PKK, Karang Taruna, Komite Sekolah, dan HKTI. Ternyata keikutsertaan mereka dalam organisasi tersebut mendorong kontaktani untuk menyampaikan kebutuhan wilayah yang dipimpinnya melalui programa

\section{Kesimpulan}

Berdasarkan hasil dan pembahasan dapat disimpulkan sebagai berikut:

1. Faktor internal dan eksternal kontaktani cukup beragam artinya tingkat pendidikan rendah, tapi ditunjang oleh pengalaman dan pekerjaan dalam kategori sedang serta pendapatan yang tinggi.

2. Tingkat partisipasi kontaktani dalam kehadiran tinggi artinya kontaktani bila diundang akan hadir dan tingkat mengajukan saran serta diterimanya saran dalam kategori sedang karena memiliki 
keterbatasan dalam mengemukakan pendapat baik dari diri pribadi kontaktani maupun situasi yang tidak memungkinkan, sedangkan saran ditampung untuk mencari prioritas program.

3. Faktor internal yang memiliki hubungan secara nyata dengan partisipasi kontaktani adalah pendidikan, pengalaman sebagai kontaktani, pekerjaan, dan pendapatan, sedangkan faktor eksternal yang berhubungan secara nyata adalah intensitas penyuluhan, kekosmopolitan, frekuensi komunikasi, dan ikut organisasi.

\section{Rujukan}

Agresti dan Finlay, 1999. Statistical Methods for the Social Sciences. Third Edition. USA: Texas A \& M University.

Asean Productivity Organization. 1994. Group Farming in Asia and The Pacific. Tokyo: Report of an APO Study Meeting.

Cristovao, A., Timothy, and Portela, J. 1994. Developing and Delivering Extension Programmes in Improving Agricultural Extension. A Reference Manual. Edited By: Burton E. Swanson, Robert P. Bentz, Andrew J. Sofranko. Rome: Food and Agriculture Organization of the United Nations.

Darusman T, Wazir A. 2001. Pengalaman Belajar: Praktek Pengorganisasian Masyarakat di Simpul Belajar. Bogor: Yayasan PUTER.

Kartasapoetra, A.G. 1991. Teknologi Penyuluhan Pertanian. Jakarta: Bina Aksara.
Pareek, U. 1984. Perilaku Organisasi. Pedoman ke Arah Pemahaman Proses Komunikasi Antar Pribadi dan Motivasi Kerja. Jakarta: Pustaka Binaman Pressindo.

Ndraha, T. 1990. Pembangunan Masyarakat. Jakarta: Rineka Cipta.

Siegel, S. 1994. Statistik Nonparametrik: untuk Ilmu-ilmu Sosial. Jakarta: Gramedia. 